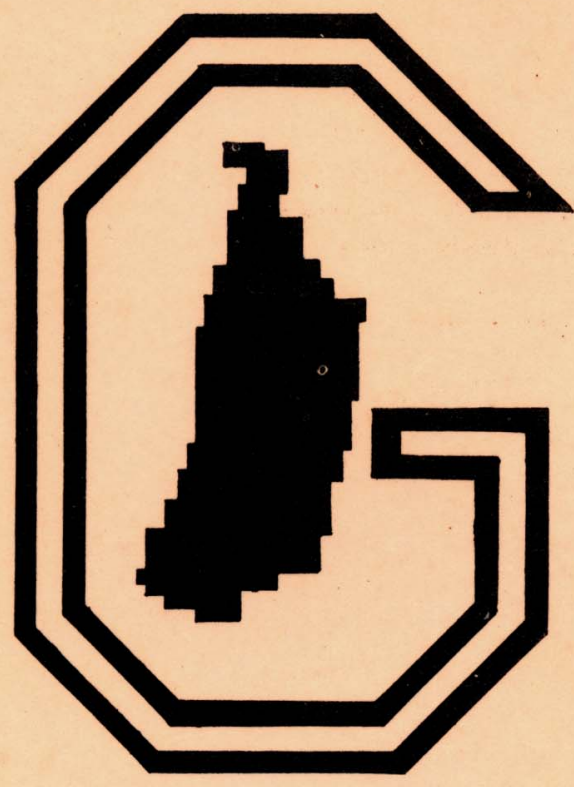

ISSN 0101.708X

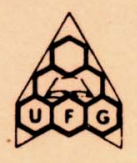

$$
\text { UFG - IOG }
$$

DEPARTAMENTO DE GEOGRAFIA
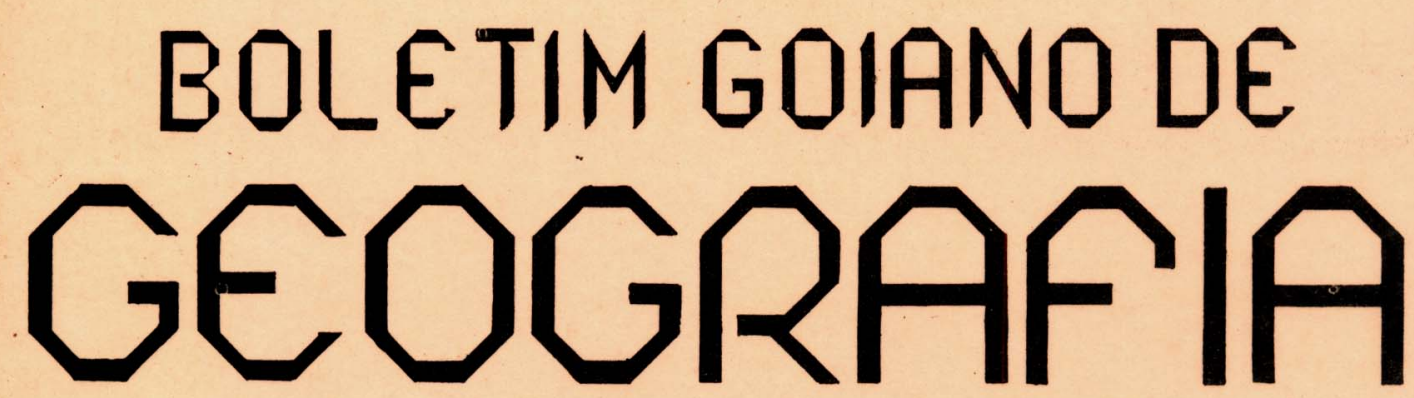

PUBLICAÇÃO SEMESTRAL - VOL. 3 N. 1-2 - JANEIRO/DEZEMBRO 1983 


\section{A PARTICIPACĀO DE GOIÁS NA GUERRA DO PARAGUAI}

\section{ZILDETE INACIO OLIVEIRA MARTINS*}

\section{ASPECTOS GERAIS DA PROVINCIA DE GOIĀS - 1860/70}

\subsection{SITUACAO ECONOMI CO-FINANCEIRA}

A economia de Goíás no século XIX se baseava no cultivo de gêneros agrícolas (arroz, feijäo, milho, cana-de-açücar) e na pecuăria extensiva, esta considerada o esteio da receita goiana, o sus tentáculo económico de Goias, isto por despender pouco capital, requerer insignificante emprego de mäo-de-obra, e por vencer, por si só, a ausência de meios de transporte $\left({ }^{1}\right)$.

A concentraçäo maior de gado ocorria no eixo norte-leste, isto devido às melhores pastagens ali existentes, e à maior proximi dade dos mercados consumidores. O gado vacum e cavalar dos rebanhos goianos começou a ser exportado em escala apreciável a partir dos a nos vinte daquele século $\left({ }^{2}\right)$.

Contudo, o desenvolvimento econōmico da província no século XIX apresentava-se entravado, devido aos fatores destacados:

- o isolamento geográfico determinado pelas grandes distâncias que se interpunham entre Goiás e o sudeste do Brasil, cen tro consumidor, que levava à rotina e à baixa produtividade da agri cultura, à ausência da indüstrias, à mediocridade do comércio, pois

- dinheiro circulante, em sua maior parcela, provinha dos cofres pro vinciais, alimentando as trocas atravès do funcionalismo $\left({ }^{3}\right)$;

- aliada ao isolamento geográfico, a precariedade dos transportes - carros puxados a bois, embarcações a remo ou vapor . demorados e caros, induzindo à exportação de gado para as províncias vizinhas, porque este por si mesmo se transportava no processo expor tador, prescindindo de viação organizada para se escoar dos centros criadores para os consumidores e, de excelente qualidade, superava os obstäculos de transportes faltos e de carreto caro;

- precariedade das vias de comunicaçāo ou mesmo a total carēncia de viação. As estradas de rodagem por vezes se apresenta vam como estreitos caminhos, intransitäeis nas épocas chuvosas, pr

* Departamento de Ciências Humanas - ICHL/UFG. 
vocando o atolamento dos carros de bois, e tornando as viagens bastante morosas.

As estradas do sul de Goiás eram, embora não satisfató rias, melhores do que as do norte, ressentindo-se essas da falta de pontes, de consertos, reparos, etc.

A navegaçäo dos grandes rios (Araguaia e Tocantins) deixavam muito a desejar.

A ineficiência da viação elevava exorbitantemente o proço do transporte a ponto de, näo raro, só ele custar o dobro do pre ço do produto transportado, o que tirava o ânimo dos agricultores de levarem seus produtos aos mercados consumidores e os obrigava a restringir a produção $\left({ }^{4}\right)$.

Segundo o presidente Augusto Ferreira França, a faita de boas vias de comunicaçäo gerava o empobrecimento das atividades industriais e agrícolas e uma diminuição do volume de transporte co merciais; acarretava, inclusive, a privação de artigos considerados como de utilização primäria, fossem eles de origem nacional, fossem produtos importados, sendo ambos não transacionados ou tendo sua pro duçäo diminuída, como forma de minimizar os riscos de não colocação no mercado, em virtude da sobretaxação pelo custo de transportes $\left({ }^{5}\right)$.

Para atender äs crescentes necessidades de transportes e locamoçäo dos seus habitantes, dispersos por todo o seu território, Goiás contava pois com sofriveis estradas de rodagem, com vias de na vegação que muito deixavam a desejar, e com meios de transporte de baixo desempenho e confiabilidade.

Durante o perícdo provincial, em Goiás apenas se contava com a utilização de estradas precariamente transitäveis $\left({ }^{6}\right)$.

outros fatores de consideräuel importância obstruiam a a ceìeração do processo econômico goi ano:

- inexistência de capitais que propiciassem 3 exploraçăo de atividade rendosas e de mercados consumidores para nossos produ tos;

- a concorrēncia sofrida pelos nossos produtos agrícolas, em relaçäo às províncias de Minas Gerals, São Paulo e Rio de Janeira que ofereciam o melhor mercadoe, portanto, maiores incentivos a pro dução. A pecuária também perdia para a província de Minas Gerais, na época grande produt ra, pois embora o rebanho goiano fosse de boa qua lidade, a maior proximidade dos consumidores favorecia os animais mi neiros $\left({ }^{7}\right)$; 
- o desconhecimento por parte das populações rurais de métodos mais rendosos de cultivar a terra e criar o gado;

- os constantes ataques indígenas, principalmente no nor te, forçando a concentração das populaçōes em pequenos nücleos, pos suidores de terras infërtels, determinando a preferēncia pela pecuária em detrimento da agricultura $\left({ }^{8}\right)$.

A associaçäo de todos esses fatores veio trazer consequên cias prejudiciais ao processo de desenvolvimento goiano, com refile xos durante decênios sobre todas as atividades econômicas aqui processadas $\left({ }^{9}\right)$.

o concurso simultâneo das influências negativas citadas sobre o binömio renda/arrecadação com deficiencias de ordem adminis trativa, criaram ao governo o problema de orçamento deficitário, uma constante a partir de $1867\left({ }^{10}\right)$, como se pode observar no quadro seguinte:

ORGAMENTO DA PROVINCIA DE GOIÁS (1868-1877) BASEADO NOS RELATOORIOS DOS PRESIDENTES

\begin{tabular}{llll} 
ANOS & RECEITA & DESPESA & \multicolumn{1}{l}{ DEFICIT } \\
\hline 1868 & $179: 467 \$ 500$ & $202: 533 \$ 269$ & $23: 065 \$ 769$ \\
1869 & $108: 488 \$ 569$ & $182: 882 \$ 156$ & $74: 393 \$ 587$ \\
1870 & $125: 123 \$ 723$ & $170: 734 \$ 756(1)$ & $45: 609 \$ 033$ \\
1871 & $125: 663 \$ 414$ & $163: 864 \$ 240$ & $38: 200 \$ 826$ \\
1872 & $148: 922 \$ 574$ & $168: 030 \$ 449$ & $19: 1075875$ \\
1873 & $147: 787 \$ 276$ & $180: 208 \$ 081(12)$ & $32: 415 \$ 805$ \\
1874 & $133: 963 \$ 818$ & $203: 259 \$ 264$ & $69: 295 \$ 446$ \\
1875 & $158: 674 \$ 316$ & $266: 161 \$ 060$ & $107: 486 \$ 744$ \\
1876 & $174: 376 \$ 898$ & $280: 904 \$ 058$ & $106: 527 \$ 160$ \\
1877 & $205: 322 \$ 081$ & $287: 388 \$ 199$ & $82: 066 \$ 118$
\end{tabular}

Segundo Nunes da Silva, solução inicial para a receita da província melhor se apresentar, seria a instituição de um fisco mais atuante, cujos agentes näo se encontrassem tão freqüentemente em situaçōes faltosas, tanto no que se refere à escrituraçäo de livros de controle fiscais, quanto por ocasiāo de suas prestaçōes de contas à Tesouraria Geral, e ainda por um maior controle desse örgão, levando à manutenção de livros que permitiram uma visão bem mais real da $r$. ceita e da despesa. 
Como conseqüencia direta da diferença entre os valores de importação maiores que os de exportação, sem grandes perspectivas de aumento desta pelos caminhos existentes, agravado o problema pelos baixos recolhimentos da receita, o que se via na província era umam biente de extrema pobreza $\left({ }^{13}\right)$.

Tentando imprimir algum progresso ao volume exportado, e como o transporte terrestre não apresentava sinais de räpido desen volvimento, o Dr. Couto de Magalhäes iniciou entendimentos sobre a navegação dos rios goianos, junto às autoridades do Ministério da Ma rinha.

Em 1865, em consequiencia da atuação das tropas expedicio närias brasileiras no território mato-grossense, e a seguir, em territário paraguaio, onde o governo provincial de Goiás se empenhava em dar-lhes sustento de víveres, estimulou-se a produçäo agro-pastoril da região, como medida destinada a garantir as fontes de abastecimen to de gêneros, que nessa hora crítica passaran a ser julgadas de suprema importância.

Apesar do esforço governamental, entretanto, ao findar a guerra o tesouro provincial estava exaurido $\left({ }^{14}\right)$.

Isto aconteceu, muito embora o Ministério da Guerra tives se tomado, a 6 de abril de 1865 , providencias para auxiliar a economia goiana, através da remessa de fundos do Tesouro, tendo visto que a débil arrecadação jamais conseguiria sustentar o contínuo fornecimento à província vizinha, sem entrar em colapso. Durante o período em que se processaram os envios de suprimentos a Mato Grosso, houve diminuição do volume de gêneros para consumo local e um aumento descon trolado nos preços.

Esta situação foi agravada com a quebra da produção agrícola, verificada no ano de 1859. "Ao final da década de 60, apresentavam-se em crise todos os setores básicos da vida da província" $\left({ }^{15}\right)$.

Nun círculo vicioso se viu o governo provinciai, quando, por dificuldade econômico-financeiras, não podia tomar providencias eficientes para combater os entraves ao desenvolvimento, como os ante riormente citados, sendo que estes, por sua vez, opunham-se ao aumen to da arrecadação $\left({ }^{16}\right)$.

o estado melindroso das finanças, em 1869, advinta assim, dentre outros fatores, dos gastos das administrações anteriores, do estado de guerra que assolava o país, e da muito diminuta renda provincial.

Procurando ativar mais o desenvolvimento econömico da pro vincia, os presidentes cuidavam de fomentar a melhoria do sistemavia 
rio de Goiás como parte de um todo de providencias que eram imprescindiveis.

\subsection{O PROBLEMA DOS TRANSPORTES E A NAVEGAGÄO FLUVIAL}

Todos os governos goianos tiveram conhecimento da precariedade do sistema viário na província.

Entre 1840 e 1870 , certos da influência negativa dessa precariedade, e cōnscios da obrigaçäo de dotar a província de um meio de transporte que melhorasse as condiçōes de vida dos locais, os governos imperial e provincial, em trabalho comum, se viram leva dos a promover a navegação fluvial, principalmente dos rios Araguaia e Tocantins, como meio de integração das regiōes ribeirinhas.

Com tal objetivo, iniciaram a tomada de providências com a criação de värios presídios às suas margens.

Apenas os rios Araguaia e Tocantins possuiam um rudimentar sistema de navegação - o primeiro, jä utilizava embarcaçōes a vapor, enquanto o segundo apenas as à vela - muito embora este fosse o mais navegàvel.

Na realidade, apenas o rio Tocantins poderia ser efetiva mente considerado como via comercial pois se prestava ao comércio en tre as províncias de Goiàs e do Parä. Por esse acesso se conseguia a compra de produtos por preços mais baixos que se adquiridos na capi tal, com uma diferença no custo de seu transporte da ordem de $50 \%$ $(17)$

A utilização do Tocantins para a navegação comercial era mais regular e constante do que a do Araguaja..Por aquele se trans portava em regime de exportação, couros e outros objetos da produ ção de Goiàs, enquanto se importava do Pará, sal, forrageme molha$\operatorname{dos}(18)$.

Durante o governo de Ernesto Augusto Pereira (1868/70) de se grande incentivo ao transporte fluvial, considerando-se seu baixo custo.

o rio Tocantins prestava-se mais ao comércio entre o norte de Gojās e o Parä; O Araguaia era visto como soluçäo para o trans porte comercial na regiäo sul-sudoeste de Goiás, entäo carente de vias de comunicaçäo satisfatórias, em economia e confiabilidade,para oxercício de um comércio regular com os outros pontos do lmpërio. 
Em 1863, foi iniciada efetivamente, por Couto de Magalhäes, a navegação a vapor do rio Araguaia. Esta linha foi oficialmente i naugurada no ano de 1868 .

Daí ate 1870 , o progresso foi acentuado, e com excelentes consequências para a melhoria económica da província.

Nesse iltimo ano, foram transportadas via Araguaia um total de quase duzentas e sessenta toneladas de produtos manufaturados de consumo e outros, a um custo de 500 réis a menos em quilo condu $z i d o$ que o preço do transporte por caminhos terrestres ( ${ }^{19}$ ).

Cumpria-se pois o interesse dos governos de dotar a provin cia de meios satisfatörios de conduçăo de seus produtos para exporta ção, o que induzia a maior produção, antes tolhida pelo desinteresse dos agricultores ou pecuaristas temerosos da perda dos resultados de seus esforços, por não terem à disposição os meios de alcançar os con sumidores.

o aperfeiçoamento das vias de exportação trouxeram maior dimensão ao desenvolvimento econônico de Goiàs.

Veremos a seguir como esta situação geral da eccromia e dos transportes vai se refletir nos dois grandes problemas suscita dos pela guerra - o recrutamento e o abastecimento.

\section{A SITUAÇĀO MILITAR E AS PRIMEIRAS PROVIDÉNCIAS.}

\subsection{A FORMAÇĀO DA TROPA DE LINHA}

A formaçäo das primeiras tropas na provincia de Goiás, sem pre mal servida de recursos militares, data de $1824 / 25$, quando se criou na parōquia de Rio claro um corpo fixo de ordenanças, sem qual quer utilidade.

Em 1836, Goiàs possuía uma companhia de cem ligeiros, que em 1838 já se reduziam a 39 .

Em 1841, foi criada uma companhia fixa de Caçadores, que no ano seguinte se tornou em corpo $f i x o$ de duas companhias, juntadas a uma terceira, de Cavalaria. Desaparecido esse corpo, criou-se no ano de 1860 , outra companhia de Caçadores.

Reformado o quadromilitar pelo governo, extinguiu-se a arma de infantaria, permanecendo apenas os Caçadores de 1860 e uma companhia de Cavalaria. Foi essa guarnição que se deslocou para co xim, agrupando-se às tropas de Minas e Säo Paulo, na defesa do terri törio mato-grossense. Tendo ali,porëm,ocorrido a falta de montarias, todas as tropas de Cavalaria presentes foram transformadas para Caça 
dores a Pé, recebendo a de Goiàs o nome de $20 \%$ Batalhão de Infantaria que perdurou até o final da luta.

Em 1870, finda a guerra, criou-se em Goiás o l: Corpo Fí xo de Cavalaria( 20$)$.

\subsection{A GUARDA NACIONAL}

A Guarda Nacional da província de Goiäs se compunha de 8 comandos superiores que abrangiam os municípios da Capital, Rio Ver de, Jaraguá, Pilar ( 1 : comando); Meia Ponte, São José do Tocantins ( 2 : comando); Bonfim, Santa Luzia ( $3 \circ$ comando); Catalào e Santa Cruz (49. comando); Cavalcante e Arraias ( 59 comando); Palma, Concelção e São Domingos (6: Comando); Porto Imperial e Natividade (70 comando); Formosa da Imperatriz e Flores (80 comando).

Estes comandos superiores compreendiam cinco esquadróes de Cavalaria, uma companhia avulsa de Artilharia, 18 batalhões de In fantaria com 98 companhias, três secçōes do batalhão com 7 companhias do serviço ativo, trēs seç̧ōes do batalhão com 6 companhias, 9 com panhias avulsas, 7 secçoes de companhia de reserva $\left({ }^{21}\right)$.

Uma vez designado o número de contingentes a serem enviá dos por cada província para a guerra, pelo decreto n? 3.383 , de 21 de janeiro de 1865 , coube a Goiás um corpo de 490 Guardas Nacionais.

Porém, difícil foi a sua organização devido ao mau estado da mesma em toda a província. Esse número de Guardas foi distribuído pelas freguesias do sul. O corpo de Guardas Nacionais, além de auxiliar o exército não somente na defesa das praças, fronteiras e costas do Império, também deveria prestar serviço de guerra no para guai.

o presidente de coiás teve dificuldades para conseguir um oficial superior com as habilitaçöes necessärias para comandar tal destacamento. Uma vez que năo oncontrava na província,solicitou ao Ministério da Guerra que fizesse a nomeação do comandante do corpo a ser composto $\left({ }^{22}\right)$.

Outrossim, enviou ordens aos comandantes dos destacamentos das cidades de Catalão, Porto Mäo-de-Pau, Santo Antônio do Rio Verde, Cachoeira Dourada, Lagoa Feia, Santa Rita do Paranaiba, no sentido de conduzir à Capital os recrutas, entregando ao comandante do destacamento da Guarda Nacional o armamento e correame que lhe fora requisitado $(23)$.

Das leituras empreendidas na documentação referente a es se contigente, nada pudemos apurar a respeito da data da sua parti- 
da em direçāo à província de Mato Grosso. Porēm, é certo que da Guar da Nacional seguiram para a guerra 263 recrutas, dos 490 designados 1 nicialmente (24).

\subsection{AS PRIMEIRAS PROVIDENNCIAS: O RECRUTAMENTO}

Com a invasão paraguaia na província de Mato Grosso, tratou Imediatamente o Governo imperial de estabelecer as medidas urgen tes e necessärias para a defesa do territörio.

Para tal. fundamentando-se na Constituição Política do lm pério, que em seu artigo 145 diz da obrigação de todos os brasilei ros a pegar em armas para sustentação da independência, para defesa contra inimigos externos e internos, e para a conservação da integri dade do Impërio do Erasil, houve por beñ o governo da naçäo exigir de seus representantes, os presidentes provinciais e seus auxiliares, a promoçăo do recrutamento, a organização de corpos voluntärios e que, em obediéncia ao Decreto n: 3.383, assinado en 21 de janeiro de 1865 , colocasse à disposição do governo central o número de Guardas Nacionais de cada província requerido $(25)$.

Pelo decreto, coube à província de Golás o fornecimento de um efetivo de 490 Guardas, tendo as diversas parōquias o encargo de tal promoçāo, cabendo a seguinte distribuicão por paróquia:

\begin{tabular}{lr} 
Paróquia & Contingente \\
\hline Capital & 20 \\
Anicuns & 12 \\
Alemão & 12 \\
Campinas & 12 \\
Pouso Alto & 20 \\
Vaivëm & 6 \\
Mossämedes & 24 \\
Corumbá & 6 \\
Santa Rita do Paranaíba & 6 \\
Barra & 20 \\
Curralinho & 6 \\
Santa Rita & 6 \\
Rio Claro & 28 \\
Bonfim & 28 \\
Santa Luzia & 28 \\
Santa Cruz & 6
\end{tabular}


Continuaçāo.

Paróquia

Contingente

\begin{tabular}{lcc}
\hline \hline Crixás & $\cdots$ & 6 \\
Traíras & & 8 \\
Ouro Fino & & 10 \\
Dores do Rio Verde & & 20 \\
Jaraguä & & 22 \\
São José do Tocantins & 12 \\
Formosa & 24 \\
Morrinhos & 16 \\
Meia Ponte & 28 \\
Catalão & $66(26)$ \\
\hline
\end{tabular}

Para o atendimento dessas exigências, o governo provincial de Goiás iniciou a nomeação de comissões municipais, através do Ato de 10 de maio de 1865, encarregando-as de promover o alistamento pa ra os corpos de Voluntários, e fazer correr uma subscrição pública destinada a socorrer as familias indigentes ou menos amparadas, dos Guardas Nacionais e dos voluntärios que marchassem para a guerra(27). Ao mesmo tempo, apelando para o sentimento patriótico dos goianos, e empenhado na defesa da dignidade nacional, ultrajada pelo inesperado ataque, convocou o auxílio de todos os cidadãos válidos para que, com toda a ajuda disponível, se pudesse vencer os paraguaios. Insistiu ser indispensävel o aumento constante dos corpos de Voluntários da Pătria, bem como o concurso permanente e eficaz da Guarda Nacional do Impërio.

Por outro lado, expediu ordens aos comandantes superio res dessa Guarda, considerando-os primeiros responsäveis pela sua organização, e designando-os naturais e primeiros agentes do governo no processo de defesa.

Recomendações foram especialmente feitas aos membros das comissões municipais de recrutamento para que minimizassem os pon tos de atrito e entrave à pronta formação dos corpos solicitados e para que tambëm tudo fizessem para o crescimento acentuado do número de voluntários.

Quanto aos efetivos da Guarda Nacional, achou-se necessa ria uma seleção de seus elementos componentes, que se determinou fos 
sem fortes, sadios, bem fardados e alimentados, armados e municiados.

Para se prevenir quanto aos problemas de transportes, que futuramente adviriam, para a remessa de gêneros aos corpos expedi cionarios, o governo proibiu, sob pena de incursäo em crime de deso bediência e sujeição a sançöes, que se recrutassem elementos väii dos para a condução de fretes, tropas e carros com destino à Capi tal, a outros pontos da província, ou para Mato Grosso ( ${ }^{28}$ ).

observou-se tambëm que "o recrutamento deveria ser feito com especial atençäo para nāo causar ofensa a direitos de isençäo do serviço militar ou prejuízos ou encargos às famílias" (29). Este tra tamento foi comunicado às comissöes para cumprimento das determinaçōes da instruçäo de 10 de julho de 1822 e da legislação enr vigor.

Deu-se ênfase à necessidade de separação fiel entre re crutados e voluntários, bem como da remessa apenas de elementos con siderados aptos para o desempenho que lhes fosse exigido.

Para fazer frente ás despesas com o recrutamento,os co mandantes superiores requisitavam o numerärio necessärio, oferecendo quitação com recibos em duplicata $(30)$.

Cada destacamento de Guardas Nacionais deveria seguir Pa ra a Capitai da província,sob as ordens de um oficial de confiança, designado em comissão. Durante o percurso, cada Guarda percebia a quantia de 340 réis diärios, pagos por antecipação, calculados os dias para esse fim, a contar da data da partida, na proporção je um dia para cada quatro ièguas de marcha ( 31 ).

Alguns comandantes encarregados do recrutamento em suas comarcas tiveram grandes dificuldades para o cumprimento dessa etapa; tal ocorreu,por exemplo, com Custódio José de Almeida Leal, encarregado da comarca de Palma, na vila de Conceiçäo do Norte, coube a remessa de 75 soldados. Teve esse encarregado a dificuldade de obtenção dos víveres necessärios para a marcha, gerada pela ca rência existente em toda a sua comarca, e agravada sobremeneira pela seca que causou grande mortandade nos rebanhos $\left({ }^{32}\right)$.

Tendo em vista a ocorréncia de värios casos de retardamen to no envio dos corpos de Guardas Nacionais, o presidente Augusto Fer reira França resolveu estabelecer normas que viejsem a completar com malor rapidez a formaço das tropas a serem destacadas e organizadas para desiocamento até Mato Grosso e as comunicou aos comandartes su periores das comarcas por intermédio de dois ofícios circulares, datados de 28 e 29 de setembro de 1865 , respectivamente ( ${ }^{33}$ ). 
Por seu lado, entretanto, julgando necessäria uma justifi cativa para täo acentuada demora, o comandante superior da comarca da Capital, coronel Antōnio Josē de Castro, fez coletar uma relaçäc. que apontava as causas do atraso:

- baixa densidade demogräfica, numa vasta extensão terri torial;

- falta de convenierte organização e, em alguns casos, o total desmantelamento da Guarda Nacional;

- incidencia relativamente grande de homens casados em relação aos solteiros, o que dificultava o cumprimento às recomenda ções presidenciais sobre direitos de isenção e gravame familiar, na maioria das paróquias;

- grandes alterações por evasão nos quadros dos Guardas Na cionais, pelo alistamento como voluntärios de elementos saídos de suas fileiras;

- morosidade na designação dos Guardas, feita na forma estabelecida pela Lei n? 602, de 19 de setembro de 1850 e seus regula mentos.

Considerando-se a validade dos argumentos apresentados, näo se pode justamente acusar de negligência ou descaso os comandan tes superiores ou seus corpos de auxiliares no recrutamento, como tambëm näo se pode atribuir à falta de patriotismo ou coragem dos goia nos, a dificuldade em tê-los na defesa da integridade nacional.

Apōs levar em conta todos os diversos aspectos desses en traves, e tentando obter mais rapidamente e em maior nümero os contingentes necessärios a defesa do nosso territörio, determinou o Mi nistērio da justiça, a 13 de naio de 1865, através de uma circular a todos os comandantes superiores da Guarda Nacional, fosse suspensa imediatamente essa unidade, nos locais em que se recusase a contri buir com a contingente exigido nos termos do Decreto n? 3.383 , e ainda sugeriu o mesmo Ministërio ao Governo Imperial fosse sumariamente dissolvida a Guarda nos locais e ocasiöes onde julgado convenien te aos interesses do Estado $\left({ }^{34}\right)$.

o presidente da província, Augusto Ferreira França,estu dando o problema do recrutamento e suas conseqüencias, observando o razoāvel nümero de Guardas Nacionais e de Voluntärios da pätria colocados à disposição do Ministērio da Guerra por Goíás, pesando o en cargo que recaía sobre a província pela sua obrigatoriedade de fornecimento de viveres às tropas em operaçäo em Mato Grosso, e a in fluência que tem o processo sobre a diminuição dos homens aproveitä veis como tropeiros e carreiros, impedindo, com isso, a remessa de 
gêneros por carência de transportadores, e julgando a conveniência de aguardar o adestramento e guarnição, em separado,dos Voluntärios e dos Guardas, resolveu, através do Ato n: 1.355 , de 19 de setembro de 1866 , suspender, por 2 meses - setembro e outubro desse ano - o recrutamento (35).

outro fato que ocorria com o recrutamento forçado era ge rar o medo que instigava os lavradores a se esconderem no mato.Essa fuga comprometia, também, a condução de viveres para a frente de ba talha, por diminuir a produção de alimentos e tornar escassos os con dutores. Foi esse um importante elemento das circunstancias que levaram o presidente frança a tomar as medidas suspensivas do recruta mento.

Apenas depois de estabelecida a corrente regular de fornecimento aos acampamentos em Mato Grosso, e reconquistada a confiança da populaçäo em seus bons propósitos, pode o governo provincial reiniciar os trabalhos de aliciamento de pessoal para a constitui ção do $2 \%$ Corpo de Caçadores a Cavalo, confirmada a sua não interferência nos trabalhos de provimento das tropas (36).

Algumas localidades não dispunham de um destacamento que pudesse se encarregar do arrolamento de pessoal, como por exemplo, Bela Vista e Natividade.o presidente Augusto Ferreira França contor nou o problema pelo envio de io praças a primeira, e 8 praças ásegunda, obtidos junto ao comandante superior da comarca de Porto $1 \mathrm{~m}$ perial.

\subsection{OS EFETIVOS GOIANOS NA GUERRA}

\section{$2,4,1,0$ BATALHÃO DE CAGADORES}

En 22 de dezembro de 1864 , o presidente Augusto Ferreira França, da província de Goiás, recebeu do Ministério da Guerra, ordens para que aprontasse o Bataihäo de Caçadores para deslocamento a té Mato Grosso.

Para reunir todos os elementos desse batalhão, o presi dente resolveu substituir os destacamentos formados por eles, atuan tes nos värios pontos da província, por membros da Guarda Nacional, deixando, apenas, permanecer onde estavam, os sediados em porto do Rio Grande, no aldeamento de sāo José e cidade de Boa vista,e nos pre sídios, isto porque seria inviävel a sua substituição e causaria o retardamento da marcha, pelo tempo que levariam para chegar à capital. 
Enquanto se processavam as substituições e o apronto, o presidente se via a braços com outros probiemas, de grande importân cia, que se opunham à partida. Entre esses, pode-se citar a série abaixo:

- para o.preparo da munição, faltavam material (pólvora, cartuchos e chumbo) e mão-de-obra;

- a pólvora grossa estocada no depósito de material béli co năo era de conveniente composição;

- era necessäria a aquisição de bestas para o transporte de viveres e de todo o material do batalhão,sendo esta possivelmente a maior dificuldade a ser vencida;

- ainda sob o aspecto transporte, era de dificil realiza ção a contratação de tropeiros, que exigiam preços elevadíssimos pa ra a viàgem;

- considerou-se insuficiente o nümero de soldados parasa tisfazer o que era exigido, sendo que parte da tropa ainda estava em viagem;

- Foi necessäria a preparação antecipada à margem dos rios que seriam cruzados, de embarcaçōes para a travessia do pessoal e das cargas.

Uma vez resolvidos todos esses casos, deu-se a partida no dia 15 de abril de 1865 , com destino à capital de Mato Grosso, pela estrada que atravessa o rio Grande, estimando-se em 60 dias o prazo necessärio para a marcha $\left({ }^{37}\right)$.

ocorreu, então,que o presidente França recebeu notícias, em 6 de maio desse ano, de que o Coxim fora invadido pelos paraguaios.

Ciente disso, ordenou que o batalhão regressasse imediatamente a Goiās, para que fosse enviado então para a região invadida, onde se juntaria às tropas expedicionärias vindas de são paulo e Minas Gerais, que também se dirigiam para aquele local ( ${ }^{38}$ ).

Dessa forma, o batalhäo partiu para Coxim no dia 24 de a gosto de 1865, atendendo às ordens do presidente da província de Ma to Grosso.

Ficou estabelecido que essa força, ao se encontrar com as de São Paulo e Minas Gerais, onde quer que isso viesse a ocorrer,de veria se colocar sob as ordens do presidente provincial de Mato Gros so, coronel Manuel Pedro Drago, ou outro presidente que em seu lu gar estivesse, desde que portador de patente superior à do seu ma jor comandante $\left({ }^{39}\right)$. 
Se isso näo acontecesse, ficaria a critério deste o estabeiecimento das providencias que deveriam ser tomadas.

o batalhäo foi alcançado em coxim, juntamente com o esqua dräo goiano de Cavalaria, pelo coronel José Antōnio da Fonseca Galväo, comandante das forças expedicionarias de minas Gerais, e desig nado comandante geral em Mato Grosso. Por sua ordem o batalhäo foi reunido ao de Voluntärios, com o que se organizou a $2 a b r i g a d a, t e n-$ do sido indicado para o seu comando o tenente-coronel Joaquim Men des Guimaràes. Naquele local, rerecebeu a designação de Batalhāo 20? de lifantaria.

Os Caçadores haviam chegado ao Coxim no dia 15 de setem bro de 1865, acardo à margen direita do rio, onde os encontrou,trés dias depois, o coronel Galväo. A chegada, seu comando era exercido pelo major do batalhäo, Joäo Gervāsio de souza perné.

En toda a documentaçáo consultada, nada consta sobre o efetivo numérico do batalhäo de caçadores.

Por outra lado, como nela tamben não são mencionadas as da tas de parlida e regresso a província, do contingente de Guardas Na cionais, aventamos a hipotese de que seus componentes foram junta dos aos cacadores. Voluntários e esquadrāo de Cavalaria,na formaça do 20 ? de ln fantaria de Goiàs.

\section{$2,4,2$, O ESGUADRÃO DE CAVALARIA}

Este corpo foi organizado pelo Ato de 31 de maio de 1865 , do presidente da província de Golas, tendo sido designado seu coman dante interino o capitäo Eliseo xavier leal $\left(^{40}\right)$, compunha-se de ufila companhia de linha e uma de volunbärios, apresentando un efetivo de 118 soldados.

sua presença na Guera do paragua se processcu a partir de julno de 1865, quando marchou oara Mato Grosso, na di recăo do co xim, para participar das operacós militares previsias para os bata lhöes que para ali já se tinham anceriomente dirigido.

seu primeiro ponto de destino era o depósito dos bahús, on de se deveria informar da localizaça do batalhão goiano de cacadores.

Na hipoteso deste se encontrar pröximo, deverian os recém chegados apressar a marcha para alcança-lo, juntando-se a ele, assim permanecendo ate receber ordens superiores de separacáa, ou que alqum fato ocorresse que a deturninasse. 
Por outro lado, se grande distancia os separasse, deveria juntar-se a quaisquer tropas brasileiras que passassem pelas imedia çös, ou seguir em frente se a nenhum outro corpo se pudesse retinir. Nesse üit imo caso, sua segunda etapa o levaria a vallinho, onde novamente seria informado da localizaçäo das forças brasileiras e, como medida adicional, também das paraguaias.

Somente se dirigiria ao coxim se tivesse notícias do estacionamento do batalhäo de cacadores naquele local, ou se fosse in formado de que sua presença era ali requerida (41).

Tendo sido tal exigência satisfeita, o esquadräo chegou ao Coxin no dia 7 de setembro de 1865 , juntando-se aos Cacadores (42), e pondo-se às ordens de joaquim lartins serradourada ( ${ }^{4} 3$ até o final da guerra.

Terminada a luta, requisitou-se, nos termos do Ato de 22 de abril de 1871, a devoluçäo do estandarte do Esquadrão de Cavalaria para que fosse depositado na caledral, o que näo foi todavia atendi do $\left({ }^{44}\right)$.

\section{$2,4,3$, O EATALHÃO DE VOLUNTÄRIOS DA PÄTRIA N? 16}

o corpo de Voluntärios da pätria foi criado, juntanente com uma companhia de Cavalaria de Linha, com a qual constituiu um esqua drão que leve como primeiro comandante o capiläo Eliseo Xavier Leal, no dia 19 de maio de 1865 , por Ato do presidente provincial, e por força de determinaçöes do Decreto n? 3.371 , de 7 de janeiro de 1365 $(45)$.

Anteriormente a essa criação, já determinara o presidencu aos comandantes das diversas comarcas que criassem corpos de voluntärios, e que sob tal designaçäo os alistassem $\left({ }^{46}\right)$.

Isso feito, recebeu o alferes Pedro Nunes Baptista Tamarin do, ordens para recolher à Capizal recrutas e Voluntários da pätrią sendo ertes detentores de maior preferencia que aqueles ( ${ }^{4} 7$ ).

Formado o batalhäo goiano de Voluntärios da pairia, reuniuse este na manhä do dia dia lo de janeiro de 1866 , às nove horas, no largo da Catedral, para que se procedesse à solenidade de bencäo de sua bandeira.

Esta, finda a cerimónia e a missa, foi entregue ao coman dante interino designado, major Manoel Baptista Ribeiro de Faria, a pós o que se ouviu o discurso de presidente provincial ( ${ }^{4} 8$ ). 
Para o mesmo local, ás oito horas da manhã de 20 desse mês foi ordenada pelo Ministério da Justiça e da Guerra a reuniäo para a partida com destino à frente de batalha.

Para facilltar ao máximo o empreendimento da marcha, o presidente já havia colocado à disposição do batalhão todos os meios ne cessärios que estavam ao seu alcance (49).

Pouco antes do início da viagem, discursaram o presidente frança, o comandante militar josé Joaquim de Carvaiho e o comandante superior da Guarda Nacional, coronel Antōnic José de Castro.

Terminadas essas formalidades, os oficlais tomaram seus pos tos e foi dada a ordem de marcha.

Nisto foi o batalhão precedido pelo presidente Augusto Ferreira franca, pelo coronel Carvalio, por funcionärios públicos e alguns cidadãos que nontados a cavalo o acompanharam pelotrecto de neia légua, ao som de banda militar. Seguiu, então, rumo ar coxim.

o batalhão era composto de 432 praças e comandado pelo coro nel josé Joaquim de Carvalho, que comunicou estarem os praças e os oficiais entusiasmados com a partida.

Seu destino era o acampamento do Coxim, onde se deveria incorporar à força expedicionária que para lá demandava, vinda de São paulo e de Minas Gerais, sob o comando do coronel José Antônio da fon seca Galväo.

Inicialmente, esse conjunto deveria permanecer acampado no co xim, de onde partiria para as operaçóes nos distritos de Miranda e Baixo Paragual, emi Mato Grosso.

Após iniciado o trajato, contratiando ordens do Ministērio da Guerra e do presidente da provincia de Goiăs, que lhe determina vam a ida imediata para o coxim, o coronel carvalho tomou com suas tropas o rumo de cuiabá.

Sabedor dessa ocorrência, comunicou frança àquele comandante que a força deveria contramarchar para o ponto inicialmerte fixado, onde aguardaria novas ordens.

Extrementes, resguardando-se contra novas possibilidades de desobediencia, ordenou ao encarregado do fornecimento de gêneros ao bàtalhäo, capitào António Gomes Pinheiro, que cortasse os suprimen tos se continuasse a marcha ao mesmo rumo. Autorizou, porém, o forne cimento do requerido se a contramarcha se realizasse.

o presidente determinou, ainda, desta feita ao alferes comandante do destacamento do Rio Grande, que não facilitasse víveres ou embarcaçães para a travessia do destacamento revel. Ao chefe de polf cia, senhor Evaristo de Araüjo Cintra, ordenou que procedesse breve 
e rigorosa sindicancia para apurar responsabilidades e conhecer os motivos que levaram o coronel Carvalho à desobediência. Desejava- se saber tambën se houve a concorrência de algum militar para provocar essa atitude do superior da força.

Aquela at:toridade partiu imediatamente ao encontro da tropa, indo alcança-la na estrada que liga o Espírito Santo ao depósito de Bahüs, a dez lëguas alëm do Rio claro.

comunicado das providéncias tomadas pelo governo, ordenou Carvaiho o cumprimento das ordens iniciais, rumando para o Coxim.

Das sindicancias levadas a cabo por cintra, ficou-se saben do que os motivos que apresentou o coronel Carvalho como justificativa para o seu procedimento foram a falta de víveres em coxime a probabilidade de alguns pontos da província de Mato Grosso, e mesmo sua Capital, serem atacados, o que seria evitado com a presença de sua tropa.

o comandante havia comunicado ao major Manoel Baptista Ribeiro de Faria que fora cienficado por um negociante de Cuiabá,F.Sam paio, dessas possibilidades, e que lhe ocorrera então a mudança de roteiro, destinando-se àquela capital.

Contrariado, porém, como fato da alteração dos planos, o coronel Carvalho resolveu passar interinamente o comando do batalhão ao major faria, o que ocorreu a 9 de março de 1866 , apos o que se guiu sozinho parà Cuiabä.

Relata Cintra, entretanto, que os motivos apresentados pelo ex-comandante não procediam, e que, na realidade, este apenas mu dou o destino da viagem para atender a interesses pessoais. Carva lho havia declarado a värias testemunhas ser de seu interesse a ida àcuela cidade, onde permaneceria inativo.

Cintra ainda o acusa de má-fé, pois o coronel carvalho,para evitar que chegasse do conhecimento do governo goi ano a notícia da marcha para a Capital mato-grossense, fez com que seus comanda dos fossem obrigados a grandes voltas e, para compensar o aumento da distância, aumentavà tambēm a jornada diäria.

Dias houve en que se marchou desde cedc até alta noite, e as vezes sob temporal. Como consequência desse esforço, os soldados se esgotaram, e se estropiaram os animais de bagagem e as bestas de carga dos tropeiros. Emagreceu a boiada, a ponto de ser necessäria a sua substituiçāo no Rio claro. Todos se queixaram das longas e for çadas caminhadas. Considere-se ainda a sobrecarga em virtude das chu vas e das enchentes dos cursos d'agua que mais ainda retardavam o desenvolvimento da viagem $(50)$. 
Regularizada a situação, o bataihão de Voluntārios deveria prosseguir atẽ Bahüs, onde se abasteceria e se informaria sobre as tropas às quais se deveria agregar. Caso não as encontrasse, deve ria demandar a Vallinho, onde teria notfcias do coxim e das forças paraguaias.

0 encontro dos voluntários goianos com as forças do bata Ihão de Infantaria no 20 ocorreu em janeiro de 1867 , no acampamento em Miranda, sob as ordens do coronel Carlos de Moraes Camisão, coman dante das forças. Este fez saber que, embora não tivessem recebido prática do serviço militar, os Voluntärios se constituíam num grupo subordinado e instruído.

Depois de concluída a sua atuação ra defesa do territörio brasileiro, os Voluntärios foram em Cuiabá dispersados de continuar - serviço militar, pelo presidente de Mato Grosso.

Em má hora chegou tal dispensa, tendo-lhes causado grandes problemas, una vez que assim ficariam sem dispor dos necessärios meios. de transporte para retorno aos seus locais de origem, considerando, alem de tudo, o alto custo de vida naquela capital.

En consequência, os Voluntários foram retornando esparsos, por seus pröprios meios, o que tornou goiäs a única província que näo recebeu seus filhos com as honras que mereciam, por todo o de sempenho que cumpriram, e por todo o sofrimento por que passaram no decurso da luta.

A única homenagem recebida foi o regresso, a Goía em 22 de setembro de 1870 , do capitäo de 20 : batalhäo, Luiz Cândido Gonzaga, trazendo por ordem do vice-presidente da província de Mato Grosso, a bandeira do extinto batainäo goiano de voluntários.

Esta bandeira foi depositada ra catedral da cidade de Goiàs no dia seguinte, 23 de setembro.

\section{2,5. A ASSISTENNCIA SANITÄRIA}

Iniciado o processo de recrutamento das forças, em 1865 , a serem enviadas à província mato-grossense, o presidente provincial joão Borifäcio Gomes de Siqueira dirigiu-se ao Dr. Theodoro Rodri gues de Moraes, delegado do cirurgião-mor do Exército, para que a prontasse uma ambulância devidamente acondicionada para a marcha do Batalhão de Caçadores atë a capital daquela província. 
Com a intenção de prestar a necessäria assistência médica aos componentes do Batalhäo, marchou junto a eles o único médico disponível, o segundo-cirurgião Dr. Cándido Manoel de oliveira.

Ainda na gestão do presidente 5 iqueira, em 18 de fevereiro do mesmo ano, foi aprontada outra ambuläncia, esta com destino ao destacamento do porto de coxim, composto de 22 prafas.

o presidente Augusto Ferreira França solicitou ao diretor do Instituto Vacínico da Corte, tubos e läminas com pus vacínico, o que foi atendido pelo Dr. Balbino de Moraes Pinheiro, Juiz do Termo de uberaba, em 26 de maio de 1866. Todos os praças do batalhão de Caçadores e da companhia de Voluntärios da Pátría, e os do esquadrão de Cavalaria foram vacinados antes da partida.

Em 18 de junho de 1866, foram enviados medicamentos às for ças em operação ac sul de Mato Grosso, então comandadas pelo tenente-coronel Joaquim Mendes Guimaräes, uma vez que o estado sanitärio delas, segundo esse mi litar, era o pior possível, observado o número crescente de doentes e a carência de remédios. Ainda segundo o co mandante das forças, grande parte das ambuláncias foram deixadas por falta de animais para sua conduçäo $\left({ }^{51}\right)$.

No entanto, a falta de medicacão obrigou o coronel carlos de Moraes Camisão a enviar à capital de Goiảs o capitão do batalhäo 20.9 de Infantaria, Luiz cändido Gonzaga, para sua obtenção, isto er: fevereiro de 1867. Em, em 24 de abril desse ano, foi-lhe enviada uma ambuläncia contendo os medicamentos solicitados.

A seguir, fornecemos uma relaçäo parcial de medicamentos en viados às forças sediados em Mato Grosso:

- no ano de 1866: 48 pares de laminas e 20 tubos capilares com pus vacínico - nos meses de março a agosto;

- no ano 1855: 2 caixas contendo laminas e tubos compus vacinico;

- no ano de 1867: 4 läninas com fluido vacínico; 2 caixas com 20 pares de làminas e 5 tubos com pus vacínico; 5 tubos compus vacínico; un tubo e uma làmina com fluído vacínico; 24 pares de 1 aminas e 5 tubos capilares com fluido vacínico; 2 caixas de remédios; uma caixa com 24 laminas e 6 tubos capilares com fluido vacinico; e uma caixa com 24 läminas e 5 tubos capilares;

- no ano de 1868: uma caixa com läminas e pus vacínico. 


\subsection{A ORGANIZAGÁO DO SERVI\&O DE ABASTECIMENTO E AS REA- Gũes da populagão. \\ 2.6.1.0 IMPACTO INICIAL E AS DIFICULDADES POSTERIORES}

Assim que se ficou sabendo da invasão paraguala em Mato Gros so, e uma vez tomadas as primeiras providencias por parte do presiden te provincial para socorrer aquela província, o povo goiano sentiuse de certa forma comovido e procurou acudir o mais prontamente passível aos reclamos dos mato-grossenses.

De início, cidadãos animados do nobre desejo de ccrrer em defesa do país, começaran a afluir, sendo os municípios de Bonfim e Cataảo aqueles que prineiro ofereceram nümero mais considerävel de soldados para o serviço da guerra.

Porém, apesar das providências tomadas pelo vice-presidente João Bonifácio Gomes de Siqueira (dezembro/64 a abril/65), no to cante ao envio de forças auxitiares a Mato Grosso, somente na admi nistraçăo de Augusto Ferreira França (abril/65 a abril/6́) foi que se conseguiu expedir o primeiro corpo auxiliar em socorro dos matogrossenses. Dentre as várias providencias por este tomadas, atinentes à guerra, sobressaem:

- a substituição das armas estragadas do bataihão de Caçadores, por outras em bom estado;

- conserto de aiguns armamentos;

- contratação de animais para o necessärio transporte dos viveres requeridos pelas tropas; e

- ordens para a compra de gêneros alimentícios que falta vam para o fornecimento do batalhão em viagem.

Assim que assumiu as rédeas da administraçāo, o presidente França achou o espírito püblico abatido, notando pouco entusiasmo na população pela sorte das nossas armas. Verificando como era prejudicial este estado de coisas, tentou muda-lo, empreendendo uma visita ao depósito de artigos bélicose aos quarteis de Cavalaria e do bata Ihäo de Caçadores, passando a este uma revista em ordem de marchaque veio a animar o povo.

Expediu trés circulares a fim de despertar o patriotismona província e por em açăo as molas auxiliares do governo:uma foi envia da para as câmaras municipais e as outras duas para os comandantes $\$ \underline{u}$ periores de Guarda Nacional, para fazer seguir para a Capital os Guar das que tinham que compor o corpo a ser destacado e os voluntärios que foram incumbidos de alistar.

Deliberou que o Correio deveria partir duas vezes por mês, daqui para o porto de Rio Grande, a partir do mês de junho. 
Foi instalada a 9 de maio de 1865, na cidade de Catalão,uma sociedade denominada "patriótica e Humanitäria", com o fim de aju dar o governo na guerra do Paraguai.

0utrossim, foram feitas värias subscriçoes em favor das fa milias indigentes dos Voluntários e dos Guardas Nacionais, que mar charam para a guerra, a saber:

- pela Comissão Paroquial no Rio Claro: cento e quarenta mil rëis;

- pela Comissão Municipal do Porto Imperial: 405.mil réis, em 1866 ;

- pela venda de reses de Pilar: 304 mil réis;

- pela vila de Santa Cruz: 913 mil réis; e

- por Catalão: $541 \mathrm{mil}$ réis.

outros ofereceram seus serviços pessoais para a defesa do Estado e certa percentagem a ser abatida de seus vencimentos. 0 alfe res reformado de Cavalaria, Gregório António da Silva, ofereceu-se co mo instrutor da Guarda Nacional de Cavalaria, por não gozar de boa saüde.

Ainda, a Comissão Municipal da Capital,enviou $3.039 \$ 000$ reis para o asilo dos laválidos, atendendo ofício de 28 de maio de 1867 , do presidente provincial, que determinou se fizesse um depósito na Tesouararia Geral das Rendas provinciais, das quantias por ele arrecadadas em benefício das famílias indigentes dos Voluntärios da Pátria e Guardas Nacionais.

Algumas senhoras se prontificaram a coser gratuitamente as roupas e fardamentos dos Voluntärios da Pätria, dentre elas destacan do-se Emerenciana Vicência do Espírito Santo, Maria Vicencia de Azevedo, Maria da Paixão e silva e Luiza lsolma da silva ( ${ }^{52}$ ).

Entre as pessoas que contribuiram comparte de seus vencimentos para auxiliar no esforço de guerra, podemos citar os que se seguem: major Manoel Pereira Cardoso (5\%); padre Serafim José da Sil va, da Paróquia de Dores do Rio Verde (5\%) professores Vicente Moret ti Foggia, José Ignäcio de Azevedo, Benedito félix de Souza e Luiz Marcelino de Camargo (10\%); $5 r$. Pedro Luiz Xavier Brandão (5\%); Sr. Luiz Thomaz de Aquino (5\%) ( ${ }^{53}$ ); capitäo Antônio Baptista Camacho (sem percentagem declarada, no período de $19 / 7 / 1865$ até o fim da guerra); Sr. José Pedroso Duarte $\left(20 \$ 000\right.$ reis) $\left({ }^{54}\right)$; Or. José Raymundo Mari nho, Promotor Püblico da Comarca de Boa Vista $(10 \%)\left({ }^{55}\right.$ ); padres Da niel da Silva Rocha Vidal e Antōnio Luiz Braz Prego, de São José do Tocantins e de Santa Cruz, (5 e $10 \%)$, respectivamente; Sr. Francisco Herculano Fleury Curado, agente do correio de Corumbä (todos os seus 
vencimentos); professores Severiana da Fonseca Braga (10\%), Ana Joaqui na da Luz (20\$000 reis anuais), Braz Luiz de pina e lvo Rodrigues bar bosa $(10 \%, c a d a ̀ m)$.

Un grupo de 52 cidadãos de Catalão doaram, para as urgencias do Estado, através de uma subscrição, uma certa quaritia não registrada.

Entre as pessoas que fizeram doação de mantimentos, podemos citar: Senhores Franklin da Rocha Lima, João Baptista Carneiro, Francisco de Faria Albernaz e o major António Pereira de Abreu.

\subsubsection{A FORMACÃAO DE DEPÓSITOS DE VİYERES}

Dada a característica da economia de subsistência, quase au tosuficiente e autoconsumidora de Goís, resultando na precaridade do comércio locai, näo existiamestoques de alimentos na província.o pro bleme foi agravado pela necessidade de abastecimento da província ma to-grossense, e, posteriormente, pela seca de 1869.

Diante disso, a primeira providencia do governo goiano foi a criaço dos chamados depósitos de víveres.

Eram os depósitos de víveres uma espécie de armazens como fim de proporcionar mantimentos às forgas expedicionárias que passassem pelas suas proximidades, de conservar os gêneros em um ponto central, de onde sairian para o suprimento das forças enquanto atuavam nos distritos de Miranda e Baixo Paraguai, em Mato Grosso.

Procurando atender a esse ültimo objetivo, o governo provin cial expedia ordens para os agentes das diversas localidades para que comprassem e remetessem para esses depósitos, gêneros e mantimentos.

os viveres comprados eram pagos pela Tesouraria da fazenda, limitando-se estas a satisfazer os pagamentos mais urgentes com dinhei ro enviado diretamente aos encarregados dos depósitos. os casos ou tros, eram i iquidados posteriormente, parcelados ou não, por meio de apresentaçäo de contas, ou por recibos firmados na recep̧ão dos gâne$\operatorname{ros}(56)$.

o acumulo de geñeros alimentícios nos depósitos era funda mental para o perfeito abastecimento das forças expedicionärias, moti vo pelo quai os agentes sempre recebiam ordens no sentido de ativar, cada vez mais suá aquisiçăo.

Tais depósitos foram criados em outubro de 1865 , destacando se dentre eles o de sant Ana de paranaíba e o de Bahüs, que se liga vam à estrada que demandava da capital da província (Goiás) a coxim, e à que saía de Vila de sant'Ana com destino a Cuiaba. 
o depósito de Bahús era dirigido pelo capitäo Spericião Bap tista Roquete Frōes e pelo tenente Beraldo José de Araújo ( ${ }^{57}$ ). Este depósito se localizava na fazenda do Sr. Antōnio Barbosa, por oferecer condições locais muito boas. O proprietário recebia pelo uso do local uma gratificação razoāvel.

Além desses depósitos, outros foram criados; no porto de Santa Rita, na fazenda do Pereirinha, no Rio Claro, no porto do Rio Grande e o da Capital.

Este üt imo foi criado pelo Ato de 15 de abril de 1867 , e era chefiado pelo capitão da Guarda Nacional Antonio de Pädua Godinho.

Os mais bem abastecidos foram sempre os de Bahūs e Rio Cla ro(58). Em 6 de novembro de 1965, havia no Bahüs mais de mil cabeças de gado(59). Em 22 de março de 1866,313 cabeças de gado foram enviadas para o Coxim, sendo parte desse lote pertencente ao depós to de Bahüs, e parte comprada pelo major primeiro oficial da Tesouraria da Fazenda.

0 Bahüs era guarnecido por destacamento de 15 praças. Estes prestavam serviços constantes de Atos expedidos pela presidên cia da província ( $\left.{ }^{60}\right)$.

Em 1865, o depósito de Bahüs abasteceu o batalhão de Caça dores, o esquadräo de Cavalaria e o batalhäo de Voluntärios da pätria, acampados no coxim, e ainda um contingente de 51 praças que con duziam artigos bélicos para Mato Grosso.

En 13 de fevereiro de 1866 , o presidente provincial Augus to Ferreira França, considerando a necessidade de compendiar as ordens principais dadas referentes ao depósito de Bahús para suprimen to das forças servindo em Mato Grosso, expediu o Ato n? 919 , que fá zia as seguintes instruções:

- destinava o depósito apenas ao suprimento das forças que passassem pela imediaçöes, das acampadas em Coxim, e quando estas es tivessem operando contra os paraguaios em Miranda e Baixo Paraguai.

- determinava a direção do depósito a pessoas designadas pe la presidéncia, e a quem esta responsabilizava diretamente por quais quer irregularidades;

- determinava da alçada da presidencia o estabelecimerto do destacamento de guarda;

- atribuía à direção do depósito a responsabilidade pela compra de todo o necessário para mantê-lo en condições de atender às forças na quantidade e no momento exigidos; 
- obrigava à manutenção de instrumentos de medida para con trole das aquisições;

- determinava a acondicionamento dos gēneros protegidos de agentes de deterioração;

- determinava a marcação e guarda dos rebanhos em pastos de boa qualidade;

- estabelecia a permanência constante de pelo menos um en carregado no depósito, e de pelo menos un em viagem de aquisiçāo, que recomendava fosse feita pelos preços mais razoáveis possíveis, visando menor desgaste nos cofres püblicos;

- determinava o pagamento das compras através da Tesouraria da Fazenda, autorizando porém o uso de verba fornecida ao encar regado para liquidaçăo en caso de nāo aceitaçäo daquela forma de pa gamento pelo vendedor. Em qualquer compra, exigia-se para comprovaçăo, recibos em duplicata, com redação padronizada;

- o depósito manteria equipes para campear o gado e trans pcrtar os gêneros adquiridos näo entregues diretamente nos armazéns

- o depósito deveria sempre fornecer a solicitado por quen de competência, enviando tambēm ao Coxim, quando fäcil o transporte, todos os gêneros disponíveis, emitindo guia minuciosa da remessa e também tomando recibo em duas vias;

- exigia a prestação de contas das aplicaçóes realizadas, bem como o controle permanente dos estoques, que deveriam ser constantemente participados á presidencia. Este controle obrigava à exis tência de livro próprio para registro das entradas e saídas dos géneros; este livro seria examinado quando da exinģão do depósito,pa ra julgamento $(61)$.

Compiementando estas instrç̧ões, expediu-se a seguir o Ato de 4 de abril de 1866 , com as seguintes determinaçós:

- pessoa do quadro da Tesouraria da Fazenda, designada pe lo presidente provincial, exercerà as funçōes de escrituração do depósito, além de executar os mesmos encargos dos demais encarregados; e esta pessoa deverá constituir tantos livros para controle quantos achar necessários, podendo esses livros, zo contrário des criados no Ato anterior, ser abertos, numerados, rubricados e encerra dos por ela pröpria;

- chefiará o destacamento de guarda o oficial mais gradua do em serviço no depósito, cabendo a este organizar os vencimentos $=$ efetuar o pagamento do soldo aos subordinados; 
- não se permitirá qualquer tipo de jogos, nem a permanéncia de pessoas estranhas no depösito, ou na casa de arrecadação( $\left.{ }^{62}\right)$. Competia ainda aos encarregados de depósitcs, a direçāo dos serviços de correio, ajustando pessoas que conduzissem as malas do depósito para o acampamento das forças expedicionärias, realizando as trocas de malas no deposito dos Bahüs.

Em funçäo das forças localizadas em Nioac, a linha do cor reio foi alterada, sendo subdividida em duas partes:uma, da capital até o Bahüs, e a outra, desse depösito até o acampamento ( $\left.{ }^{63}\right)$.

Além das determinações constantes dos Atos 919 e seu complementar, o presidente França procurou manter as autoridades militares informadas dos locais onde pudessem ser adquiridos gēneros al mentares e gado, recomendando sempre, porém, prioridade para aquisi çäo de cereais, por serem mais necessärios na ëpoca.

Com a finalidade de aumentar a concorrência dos negociantes junto às forças, e como contribuiçăo para evitar o aumento desregulado dos preços dos víveres, foi vedada a compra direta de carreiros e tropeiros pelos encarregados dos depositos.

Com o passar do tempo, receiando a deteriorizaçăo por não poderem ser imediatamente consumidos os gēneros, o presidente França recomendou se regulassem as compras para o depósito dos Bahús $\left({ }^{64}\right)$. Näo se podia correr os riscos de perda de viveres, nem tam pouco os de deixar as forças sem meios abundantes de subsistēncia.

Em 21 de janeiro de 1867 foi extinto o depósito de säo Pe dro, administrado por serafim Jose de Barros.

Em 5 de novembro desse ano criou-se um depósito no Coxin, com o comando exercido pelo alferes do destacamento, Antōnio Pinheiro de 01 iveira.

Autorizou-se, a 10 de novembro de 1868 , por desnecessäria a sua existēncia, uma vez que não haviam mais forças no sul de Mato Grosso, a extiņ̧ão do depósito dos Bahüs.

o presidente da província de coía encarregou uma comis säo de ir àquele local, como intuito de tomar as necessärias provi dências para a suspensāo das atividades. Estas providências seriam:

- vender à vista, pelo melhor preço, todos os gēneros que estivessem em bom estado e os recuperáveis, o gado e os animais de transporte, os utensílios e instrumentos de peso e medida;

- dar para consumo os gêneros deteriorados, após exame por tëcnicos para esse fim designados;

- entregar, contra recibo,o material requisitado pela pre sidência ou pela Tesouraria da Fazenda, vendendo o não procurado;ca so näo ocorresse a venda, entregär às māos de pessoa de confiança; 
- o material bélico, entregar sob a guarda de pessoa idonea, mediante garaltia,ficando essa pessoa encarregada de fazer chegar o de pósito à presidencia da província de Mato Grosso;

- retornar, juntamente como destacamento, conduzindo os livros de registro e toda à documentaça do depósico ( $\left.{ }^{65}\right)$.

- eri caso de se encontrarem tropejros interessados en conduzir os artigos de querra encontrados para a província de Mato Grosso, a Tesouraria estava autorizada a contratar o transporte, por un preço má ximo de dez mil réis, preço estabelecido a pedido do governo daquela provincia $(66)$.

\section{6,3, O SISTEMA DE COMPRA E REMESSA DE VIVERES}

Preocupacão constante do presidente provincial de Goiás foi a aquisicão de víveres para o abastecimento das forcas sediadas na pro víncia mato-grossense.

As forcas enviadas àcquele local (batalhöes de cacadores, de Cavalaria. de Voluntáros) foram acompanados por diferentes tropas de animais, conduzindo grande quantidade de víveres, para que não sofressem privaçoes en seu trajeco ou en sua permanencia.

inteirando-se de que as forgas de Minas gerais e de São paulo passariani pela província de Goías, rumando logo em seguida para Mato Grosso, o presidente Augusto ferreira Franca dirigiu ofícios aos di versos administradores dos distritos de Santa Rita do paranaíba, en mea dos de 1865, solicitando o aproveitamento dos gēneros produzidos e espalhados pelos diversos lavradores daquelas localidades. Todos essesví veres deveriam ser concentrados no porto de Santa Rita para serem vendidos aos comandantes das forças em tránito.

Determinou, por outro iado, que se comprassem viveres nas fa zendas mais afastadas, ainda que fosse necessärio o seu transporte en carretas, autorizando se lançase mão de verbas dos cofres da Recebedo ria e, ná sua falta, que se realizasseri as compras a crédito, debita das à Fazenda Geral.

Como os lavradores se dedicassem à pequena agricultura,prati camente para o consumo doméstico, foi criado um grande corpo de agen tes $\left({ }^{67}\right)$ que eram incumbidos de remeter viveres, quer para o depósito criado em Bahüs, quer diretamente para as forcas.

Tendo sido muito reduzida a colheita no ano de $1865\left({ }^{68}\right)$, causando escassez dos gẽneros de primeira necessiade, e provocando eleva çă de seus precos, ocorreu que qualquer extravio de mantimentos pas sou a ser bastante prejudicial e comprometedor. Daí, aumentou a impor 
täncia e a responsabilidade dos agentes para regularizar o abastecimen to das tropas.

Para que se fornecessem viveres na proporcảo em que era im prescindivel ao consumo imenso. Foi necessärio expedir carros e tro pas de carga da Capital, uns após outros, transportando géneros, e os adquirir nos municípios de Bonfim, Cataläo, Jaraguá, Hela ponte,e comarcas de Anicuns, do rio Marantăo, Alemäo e outros lupares. presi dente da Camara Municipal da Capital, Franklin da Rocha Lima, foi en carregado de pessoalmenze ir aos distritos de Curralinho, Campininhas, Pouso Alto e Morrinhos para obter viveres e meios de transporte.

sod grande pressão ficou a província, cendo sobre si a tre menda responsabilidade de näo deixar perecerem milhares de brasileiros que deferdiari a provincia mato-grossense, pressäo esta que se aqravava rapidamente, porque as forcas paulistas, mineiras e noianas se interna vara pelo distrito de Miranda, aumentando a distancia enire si e as localidades de onde provinham os neios de subsislencià. E mais ainda, o problema se tornou mais grave quado os pequenos fornecinertos que vinham de Minas Gerais e de säo paulo depressa cessaram.

Esca pressào obrigou a presidencia provincial a manter, por longo tempo, o grande numero de agentes encarregados das compras e reries $s$ as.

Para requlamentar o trabalho destes, das comissöes municipais e dos empregados dos depósitos foram formuladas instrucöes, aprovadas pe io Ministério da Guerra. Estas instrucōes foram expedidas através do Ato n: 920 , de 13 de fevereiro de 1866 , pelo presidente Augusto Ferre ra França determinavam:

-os agentes deveriam adquirir a guanidade possível de víveres, especialmente gado, arroz, feijäo, farinha, rapaduras, e enviá-las às tropas estacionadas em Coxin, ou para o depósito de Bahus, juntando a quia de remessa através do condutor:

- os agentes deveriam providenciar a aquisicão fazendo-o pelo preço mais razoàvel, bem como conseguir precos baixos tambeam para o transporte, exigindo sempre recibos em juplicata pelos pagamentos feitos diretamente. Em caso de compras feitas a credito da tesourarla da Fazenda, forneceriam declaraçōes de débito, oficiando à presidénciaso bre tais ocorrencias. Para os vendedores que aceitassem o pagamentocon tra entrega no depósito de Bahüs, emitir-hes-iam as guias necessārias oficiando aos encarregados do depósizo. Aos fazendeiros que prcpuses sem entrega diretamente nos destinos, encarecer-lhes-iam a urgência do envio; 
- os agentes deveriam incentivar a produção, colheita, armazenamento e acondicionamerto do maior volume de generos junto aos fazen deiros e lavradores;

- as prestaçōes de contas deveriam ser feitas na Tesouraria da Fazenda, devendo os agentes, para tal, apresentar toda a documenta çä tanto de despesas e receitas, como das requisições de gêneros que Ihes foram feitas pelas pessoas competentes;

- a todas as recomendaçōes reclamava-se a presteza e pontua lidade no cumprimento $(69)$.

Sabe-se que, inicialmente, o gado da Naçäo a ser remetido às forças no coxim ficava sob a guarda e vigiläncia dos encarregados do depósito de Bahús.

Porén, como ocorreu a apropriação ilegal de algumas reses por pessoas desconhecidas, e como o local näo oferecia condição de bons pastos, como recomendava o Ato ne 919, já citado, o presidente França determinou a formação de um depösito especial para o gado, em lugar seguro e de bons pastos, fazendo o trasiado de todo o rebanho. Desse novo depósito ele seria remetido para Mato Grosso para ser ali utilizado. Coube tal incumbencia a David claudino da $\$$ ilva, em 20 de jutho de 1866. Desta forma, o depósito de reses anexo ao Bahlis foi su primido. Antes da emissão dessa ordem, Bahüs havia recebido uma boiada adquirida e enviada pelo presidente provincial.

Apesar dessa ocorrência, e da existencia dos depösitos em Goiás, já desde 1865 se remetia gado diretamente para a província de Mato Grosso $(70)$.

Em certas ocasiöes, as notícias recebidas sobre o estadodas forças eram incoerentes. Por vẽzes, diziam que haviam falta de vive res no acampamento, o que provocava queixas dos soidados ("o arroz, a farinha e feijäo näo chegavam para eles, mas sim para os oficiais"l). Em 1866, o coronel Antōnio da Fonseca Galväo (71), reclamou ao presi dente França quanto à falta de viveres para as forças expedicionárias sob seu comando.

A vista das requisiçōes do atual comandante das forgas em operaçöes, o presidente da província de Golás solicitou ās autorida des militares e pessoas competentes, que providenciassem atendimento, fazendo a remessa de viveres e gado para aqueie local ( ${ }^{72}$ ).

No noticiärio do Correio Mercantil n? 100, da Corte, lê- se - seguinte sobre o fornecimento de viveres às forças sediadas no co xim:".. as forças no coxim nunca ficaramen tempo algum reduzidas à miséria, desde que ali chegaram tiveram o que comer e suas condicöes foram progressivamente melhorando.os abundantes fornecimentos que tēm sido feitos às forças, remetendo víveres por conta do governo e dos 
particulares, tanto desta Capital como de todos os lugares ao sul da província, são devidos em grande parte às facilidades criadas pela administraçäo do presidente Augusto Ferreira França näo poupando meios para suprir de víveres as forças, e ao patriotismo do povo goi ano'( ${ }^{73}$ ). E certo que nos Bahús havia viveres em abundancia,porém à falta de meios de transporte para os levar às forças eram minguados em consequéncia da peste que dizimara os cavalos e os muares, e aindapor que não havia tropas a serem alugadas ou compradas na província.

Procurando solucionar tal problema, o presidente França of ciou aos presidentes das províncias de são paulo e Minas Gerais, solicitando o envio de pelo menos trezentas bestas, a serem empregadas na condução de víveres dos Bahüs, Coxinie outros depósitos circunvizinhos até o ponto en que o exército estivesse sediado.

Provisoriamente, porém, foi suspensa a compra de novos víve res devido ao grande acumulo de provisöes nos depósitos e áfalta dos necessärios meios de transporte para os conduzir. Esta orden foi revo gada quando apareceram muitos tropeiros e carreiros procedentes de cuiabä, Minas, Säo Paulo, e mesmo goianos.

Quase todas as tropas goianas empregadas no coxim se encontravam a serviço do governo, ao conträrio das outras que eram, na sua maioria, particulares.

Pelas informaçöes do Sr. José Antönio de Souza, que estivera no Coxim no més de fevereiro de 1866 , chegaram 3 tropas com 80 bes tas e 4 carros de víveres, durante o período em que lá se encontrava.

Informou, tamberm, que durante o seu regresso, distante do a campamento quinze dias de marcha, encontrou meis oitenta bestas e trés carros de carga com viveres. Antes de chegar ao Bahüs, passou por outras 60 bestas e mais de duzentas reses.

Ainda segundo suas informações, do depósito de Bahüs, nodia de sua saída para a Capital, partiram para o Coxim cerca de 200 reses, ficando outro tanto para ser logo remetido. No Bahús, vira dez carros de víveres, não sabendo serem de particulares ou se da Naçäo.

Na azenda do Gabriel, distante de Bahüs 17 léguas, encon trou-se com uma boiada de 50 a 60 bois e com dois carros que demandavam àquele posto.

Nessa època, Serafim José de Barros enviara 400 reses para o coxim.

Coli a força do capitäo Joaquim Martins Xavier serradourada, chegaram ao Coxim, de 25 a 28 de fevereiro de 1866 , cento e vinte reses. 
Atendendo às solicitaçós dos agentes, conforme as recomendaçōes do Ato n? 920 , os lavradores aumentaram as suas plantaçöes e em breve muitos especuladores começaram o transporte de generos para ven dê-los, por conta própria, no depósito ou no acampamento.

Reconhecendo ser prejudicial aos interesses da fazenda amul tiplicidade de agentes, uma vez controlados os fornecimentos aos depó sicos, o presidente França conservou apenas um agente em Rio Verde e outro no Rio Claro, permitindo ainda que a comissão de Bonfin conti nuasse a remeter os gêneros que em abundancia mantintia acumulados $\left({ }^{4}\right)$. Foram enviados pela comissäo umi total de i04 carros de víveres (ver quadro).

MAPA DOS GENEROS REMETIDOS PELA COMISSÃO DE BONFIM, PARA OS DEPOSITOS DE COXIM E BAHUS, FOR CONTA DO GOVERNO PROVINCIAL NOS ANOS DE 1866/1867

\begin{tabular}{|c|c|c|c|}
\hline$A R T / G O$ & UNIDADE & 1866 & 1867 \\
\hline Farinha de & alqueires & $9: 4$ & 27 \\
\hline Mandioca & I idras & - & 2605 \\
\hline \multirow[t]{2}{*}{ Feijào } & alqueires & 688 & 44 \\
\hline & lioras & - & 19290 \\
\hline \multirow[t]{2}{*}{ Arroz } & alqueires & 181 & 87 \\
\hline & libras & - & 11126 \\
\hline Toucinho & libras & 29130 & - \\
\hline \multirow[t]{2}{*}{ Açücar } & i ibras & 31901 & 9742 \\
\hline & sacas & - & 99 \\
\hline \multirow[t]{2}{*}{$5=1$} & alqueires & 95 & 173 \\
\hline & libras & - & 12453 \\
\hline Café & libras & 6730 & - \\
\hline Polviltio & alqueires & 1 & - \\
\hline \multirow[t]{2}{*}{ Pano } & varas & 3169,5 & 556 \\
\hline & sacas & - & 404 \\
\hline Farinha de & alqueires & - & 154 \\
\hline Milho & libras & & 24774 \\
\hline
\end{tabular}

FONTE: CORREIO OFFICIAL N.80, de 11 de maio de 1867, p.2-3. 
A idéia capital foi de ir, progressivamente, concentrando no depósito todas as operaçöes necessärias para se efetuar a aquisiçăo e remessa de víveres para o acampamento, isso porque dessa con centração resultaria a queda dos preços (porque diminuiria a concor rência dos compradores), maior regularidade nos transportes (porque todos os vé́culos deveriam afluir para o depósitol, fiscalizaçãomais rigorosa e fiel dos dinheiros püblicos. A falta de dinheiro nos co fres da Tesouraria da Fazenda impediu o presidente França de supriro chefe dos Bahus com fundos suficientes para acudir às despesas.

Sabe-se que, devido à necessidade de recolher os gēneros a l imentícios transportados em carros ou animais para as forças que saí ram do Coxim para se sediarem nas imediaçōes do rio Negro (julho de 1866) e que não pudessem prosseguir até o encontro das mesmas, folen viado ao coxim um oficial (75) que tomasse sob sua guarda os víveres até que estes fossem conduzidos em outros carros ou animais. A presen ça desse oficial era deveras importante naquele posto, uma vez que $i$ numeros condutores ficavam ali parados sem saber a quem os entregar. Alguns não podiam continuar viagem por näo haver quem lhes garantisse um frete adicional pela extensão que tinham ainda que percorrer.

Esse oficial deveria também formar duas casas de arrecadação, uma para receber os víveres vindos de Minas Gerais e säo paulo, e outra para os da província de Goiás.

Com relação ao preço do frete, é bem verdade que o trans porte de cargas em tropas ou em carros foi estipulado a $8 \$ 000$ réis por arroba, até o Coxim.

Segundo consta do noticiärio do Correio Mercantil niloo da Corte, a taxação do frete a esse preço criava obstäculos ao fornecimento de víveres às tropas expedicionärias porque muitos tropeiros exigiam melhor remuneração por peso transportado. Por outro lado, ou tros carreiros e tropeiros achavam vantajoso esse preço, pelo fato de receberem um adiantamento sobre a quantia devida.

Em outubro de 1866 , foi autorizado um aumento do preço do frete para 123000 rëis, se näo se conseguisse encontrar por menos um transporte räpido e garantido para os gêneros.Em compensação, foi es tabelecida uma nova cláusula no contrato celebrado pelos encarrega dos de depósito dos Bahüs, que obrigava o transportador dos mantimen tos a os entregar onde quer que estivessem as forças.

Foi liberado o pagamento de um frete adicional aos carreiros e tropeiros, do Coxim até o acampamento das forças que seria efe tuado pela caixa militar que acompanhava os expedicionärios, ou mesmo pela Tesouraria da província, caso aquela não o fizesse. 
o capitäo speridiäo Baptista Roquete Fröes recebeu também o encargo de abrir ow melhorar uma estrada entre Bahús e Camapuã, por se ter resolvido que os gêneros deveriam ser conduzidos para as forças que seguiram para Miranda passando por esse local, ao inves de por co $\operatorname{xim}\left({ }^{76}\right)$.

Os primeiros condutores de cargas de camapua para diante, en frentaram dificuldades com a desobstruçä da estrada de Nioac que se achava abandonada, com a construçäo de pontes sobre os diversos ribe! röes que atravessavam de leste a oeste, com as chuvas de maio que encheram os pantanais tornando-os intransitäveis, fato este que impedia a remessa de gēneros de Coxim para o Dabóco, e dali para o Nioac.A fal ta de comunicaça ofjoial dos diversos comandanetes das forças embara çava a renessa de víveres (não se sabia o ponto para onde deviam ser remetidos depois que desocuparam o acampamentc do coxim) e, consequen temente, junto com as dificuldades de trajeto, viam-se obrigados os encarregados dos depósitos a fazer contratos com os condutores, debaixo de mil condiçóes e obstäculos que estes apresentavan.

Apesar das imensas crises debeladas a principio, pare se ob ter os víveres na quantidade necessäria às forças expedicionärias, fal ta dos meios de transporte exigidos, as grandes distancias que se interpunham entre a provincia de Goiás e os locais que sediavamas ba ses das tropas, locais esses quase sempre desertos e, às vezes, areno sos e junto a rios cujas margens desmoronavam no tempo das chuvastor renciais, a provincia promoveu o abastecimento das forcas mesmo depois que elas saíram de Mato Grosso, penetrando no districo de Miranda, em território paraguaio.

Ainda sabendo da melhoria da situaça das forças no coxin, e coma notícia de que muitos carros procedentes de Minas cerais al cançariam aquele local com víveres e gado para suprimento, os esfor ços para a obtençăo de gêneros continuaram ( ${ }^{77}$ ).

Nos fins de 1866, normaizara-se o envio de gado e de víveres. Solucionado o probiema da remessa, esses passaram a ser enviados somente para Miranda ou Nioac. Em julho de 1867 , no depósito de Bahús e no acampamento das forças em Mato Grosso, existia avitada quantida de de gêneros. Pelas correspondencias dos comandantes militares aopre sidente provincial de Goiás sobre o recebimento dos víveres, notava se que suas remessas eram freqüentes e abundantes $\left({ }^{78}\right.$ ).

Tendo desaparecido a necessidade de preservação do depósito de Bahis (1868), uma vez que a força existente na fronteira foi recoInida a capital e a província mato-grossense se livrara da invasãodos paraguaios, encerraram-se as 5 uas atividades. 


\section{NOTAS E REFERẼNCIAS}

1) MoRAES, Maria Augusta Sant'Anna, Aspectos econōmicos, sociais, administrativos e culturais de Goiàs - Impērio.In: Hístōria de uma oligarquia: os Bulhöes. Goịania, Oriente, 1974 , p. 27.

2) BRASIL, Americano do. Do primeiro império à repüblica de 1889 . $1 n$ : Sümula da histöria de Goías. 2. ed., DEC.1961. p.99.

3) CORREIO OFFICIAL.RPPGO. $1873, \mathrm{p} .3$

"A agricultura nada tem feito e nem promete fazer erquanto permanecer esta província separada e privada de comuni cações fäceis com o litoral'.

4) CORREIO OFFICIAL, RPPGO, $1873 . \mathrm{P} .3$.

"O agricultor sabe que não pode exportar seus gêneros, que deve produzir o mínimo para não perdê-lo, portanto não se esforça e pouco produz. Porisso a província passa por cri ses de carestialt.

5) CORREIO OFFICIAL.RPPGO, 29 de abril de 1867. P. 37.

6) MORAES, Maria Augusta Sant'Anoa. op. cit.,p.30.

7) Idem, ibidem. p.31.

8) DoLes, Dalísia Elizabeth Martins. A expansão da indüstria agro-pastoril e a navegação. In: As comunicações fluviais pelo Tocantins e Araguaia no século XIX. Goiânia, Oriente, 1973. p.74.

9) MORAES, Maria Agusta Sant Anna.op. cit., p. 28.

10) Idem, ibidem, pp. 29-30.

11) O valor de deficit constante dos documentos estä incorreto.A diferença é de 45:611\$033, entre a receita e a despesa.

12) O valor do déficit constante dos documentos está incorreto. A di ferença é de 32:420\$805, entre a receita e a despesa.

13) OOLES, Dalísia Elisabeth Martins, op. cit., p.74.

14) MORAES, Maria Augusta Sant'Anna op. cit., p. 30. 
15) DoLes, Dalísia Elisabetin Martins.op. cit., p. 73.

16) Idem, ibidem, p. 73 .

17) TEIXE!RA, Pedro Ludovico. Relatörio - Navegação Fiuvial.1930-1933. P. 35 .

18) Idem, ibidem, p. 35 .

19) idem, ibidem, pp. 39-43.

20) BArroso, Gustavo, Século XIX. Brasil-Impërio; Regência. In:Historia Militar do Erasil. 2.ed., São Paulo, Nacional.v.49.pp.60-61.

21) CORRE10 OFFICIAL.RPFGo, 17 de junho de 1867 , n.185. p. 2.

22) CORRESPONOENCIA do Presidente da província com os Ministërios. 26 de maio de 1865, SDEGO, i ivro n.85.

23) CORRESPONDENCIA do Governo Provincial às Autoridades de fora militares de 1861 a 1865. SDEGO, i ivron.79.

24) FRAgoso, Augusto Tasso. Invasäo do Urugual por Venãncio flores à testa da cruzada libertadora - Dificuidades com a Argentina a quem o Uruguai acusa de parcialidade - Situação das relacões entre o Uruguai e o Brasil - A missäo Saraiva - Tentariva de pacificaçäo - Ultimatum de saraiva - o Brasil provi dencia sobre as represalias - Rompimento do Uruguai com o Império - Retirada de Saraíva e suas sugestöes quanto às re presálias - 0 Exército do Sul - operação comflores - Ins truções do goverio a Tamandaré e Mena Barreto - A aliança com Flores - Tropas brasileiras invadem o Uruguai - Opera çós de Tamandaré e flores contra o Salto de Paysandü - Mar chas de Mena Barreto no Estado oriental - Segundo ataque a Paysandú com colaboraçäo de Mena Barreto - Marcha dos bras $i$ leiros e de Flores contra Montevidéu - A missão Rio Branco. In: Histöria da Guerra entre a Tríplice Aliança e o Paraguai. 2.ed. , Rio de Janeiro e são Paulo. Freitas Bastos S.A., 1956, v.5. p. $26 i$.

25) CORREIO OFFICIAL, 4 de Outubro de 1865, n.95. p.4.

26) CORREIO OFFIClAL, Noticiärio, 25 de março de 1865, n.46.P.2.

27) CORREIO OFFICIAL, RPPGo, 22 de junho de 1867, n.186. P. 2. 
28) CORREIO OFFICIAL, 22 de junho de 1867, n.186.p.2

29) CORREIO OFFICIAL, RPPGO, 22 de junho de 1867, n.186. F.2

30) CORRESPONDENCIA do Governo Provincial às Autoridades de fora mili tares de 1861 a 1865. SOEGO, livro n.79.

31) CORREIO OFFICIAL, 27 de dezembro de 1865, n. 109. p.3.

32) CORREIO OFFICIAL, 10 de maio de 1865, n.53. p.3.

33) CORREIO OFFICIAL, Ofício,22 de junho de 1867, n.186, p.2.

34) CORREIO OFFICIAL, RPPGO, 7 de janeiro de 1867, n.168. p.3.

35) CORREIO OFFICIAL, RPPGO, 22 de junho de 1867, n.186. p.2

35) CORREIO OFFICIAL, RPPGO, 16 de abril de 1867, n.178.p.2.

37) CORRESPONDENCIA do Governo Provincial às Autoridades de fora mili tares de 1861 a 1865 . 15 de maio de 1865. SDEG0, livro n.79.

38) CORRESPONDENCIA do Governo Provincial às Autoridades de fora mili tares de 1861 a 1865 . 17 de maio de 1865. SDEGO, livron.79.

39) CORREIO OFFICIAL, 10 de junho de 1865, n. 126. p.4.

40) CORRESPONDENC:A do Governo Provincial às Autoridades de fora mili tares de 1861 a 1865. 3 de junho de 1865. SOEGO, livro n.79.

${ }^{\prime A}$ la.recebeu a denominação de la, e a outra de za."t

41) CORREIO OFFICIAL, 4 de abril de 1866, n.126. p.4.

42) CORRESPONDENCIA do Governo Provincial às Autoridades de fora mili tares de 1861 a 1865,3 de junho de 1865. SDEgo, livro n.79.

43) Correspondencla da Tesouraria da Fazenda - de 1866 - 1869 . 18 de março de 1867. SDEGo, livro n.90.

44) CORREIO OFFICIAL, RPPGO, 11 de julho de $1871, \mathrm{n} .376$. p.l.

45) CORREIO OFFICIAL, 24 de maio de 1865, n.57. p.1.

46) CORREIO OFFICIAL, Noticiärio, 19 de agosto de 1865. n.82.p.4.

47) CORReio OFFIClAL, Noticiário, 25 de março de 1865, n.46. p.2 Voluntários enviados pelas comarcas que mais contribuíram com elementos humanos para a formação do batalhão: comarca de flo 
res(50); Santa Luzia (30); Catalão (27); Corumbá (25); Jara guà (18); Bonfim (17); Rio Verde (12).

48) CORREIO OFFICIAL, 1866, n.111, P.1.

49) CORRESPONDENCIA do Governo Provincial às Autoridades de fora mil tares de 1861 a 1865. 6 de fevereiro de 1865. SDEGo, livro ก.79.

50) CORREIO OFFICIAL, 3 de abrii de 1866, n.125. p.3.

51) CORREIO OFFICIAL, 13 de outubro de 1866, p.8.

52) CORREIO OFFICIAL, 22 de março de $1865, \pi .46 . p p .1-2$.

53) CORREIO OFFICIAL, 8 de junho de 1865, n.9. p.l.

54) CORRESPONDENCIA do Governo Provincial às Autoridades de fora mil i tares de 1861 a 1865. SDEgo, livron.79.

55) CORREIO OFFICIAL, 7 de julho de $1866, \mathrm{n} .142$, p.5.

56) RECISTRo de Correspondencia da Secretaria do Governo - 1865-1867. i) de janeiro de 1866. SDEGO, livro n.87. pp.11-12.

57) Outros comandantes: tenente Cyriaco José d'Azevedo (i8 de março de 1866) ; capitão joaquim Martins Serradourada (17 de março de 1866). Gratificaçăo: cem mil réis.

58) CORRESPONDENCIA do Presidente Provincial às Autoridades de fora da prcvíncia - 1858-1873. 16 de agosto de 1867.SDEGo, 1i vro $n .70,0.29$.

59) CoRrespondencia do Presidente provincial às Autoridaces de fora da provincia - 1858-1873. 6 de novembro de 1865. SoEgo, livro $\mathrm{n} \cdot 70 \cdot \mathrm{p} \cdot 30$.

60) CORREIO OFFICIAL, II de agosto de $1866, \mathrm{n} .147$.

61) CORREIO OFF!CIAL, 3 de março de 1866, n.118. pp.4-5.

62) CORREIO OFFICIAL, 10 de abril de 1866, n.127. P.3.

63) CORREIO OFFICIAL, 20 de outubro de 1866, n.157. p.2.

64) Poderia ocorrer a falta de condutores de víveres.

65) CORRESPONDENCIA do Presidente da Província com diversos-1867-1872. 10 de novembro de 1868. SDEGO, livro n. 92. 
66) CORRESPONDENCIA da Tesouraria da Fazenda - de 1866-1869.11 de mar ço de 1869. SDEGO, livro n.90.

67) CORREIO OFFICIAL, 3 de março de 1866, n.118. p.6.

Vicente Ferreira Ramos de Azevedo (agente em Anicuns),

Francisco de Paula Ferreira, António de Carvalho, Manoel Pe reira Valle (agente no Pereirinha), Serafim José de Barros (agente em São Pedro), José Joaquim Leäo, José Manoel Vilel la, José Francisco Guimaräes, Antônio Gcmes Pinheiro, Ma noel Vieira de Rezende.

68) CORREIO OFFICIAL, 3 de julho de 1867, n. 187. p.1.

69) CORREIO OFFICIAL, 3 de março de 1866, n.118, p.5.

70) CORREIO OFFICIAL, 3 de julho de 1867 , n.187. p.l.

Em 5 de novembro de 1865 , foi enviada uma boiada de duzentas reses rumo a Cuiabá.

71) o coronel Antônio da Fonseca Galväo era comandante geral das forças expedicionárias em Mato Grosso. Viera comandando a for ça expedicionäria de Minas Gerais.

72) CORREIO OFFICIAL, 9 de setemtro de 1865, n.88. p.1.

- capitão Antōnio Gomes de Pinheiro e Manoel Vieira de Resende redobraram os esforços para acudir as forças, envian do víveres para Bahús ou Rio Claro. Ao comandante encarregado do depósito dos Bahús solicitou a intensificação da remessa de víveres para o Coxim e que mantivesse o coro nel Galvão sempre informado dos gêneros existentes no depö sito. Ao comissärio José Joaquim Leão, mandou colocar à dis posiçäo das forças as boiadas que necessitasse encaminhar.

73) CORREIO OFFICIAL, maio de 1866, n.137. p.l.

74) CORREIO OFFICIAL, 11 de maio de 1867, n.180. pp.2-3.

75) CORREIO OFFICIAL, 4 de agosto de 1866, n.146. p.1. Capitäo Speridiāo Baptista Roquete Frōes.

76) REgISTRo de Correspondência da Secretaria do Governo-1865-1867. 29 de janeiro de 1867. SDEG0, livro n.87. p.115.

77) REgistro de Correspondencia da Secretaria do Governo- 1865-1867. 21 de maio de 1867 . SDEGo, livro n.87. p.59. 
78) CORREIO OFFICIAL, 3 de julho de 1867, n.187. p.3. Oficio n: 50 do coronel comandante Carlos de Moraes Camisão ao presidente Augusto Ferreira França - Acampamento em Nioac, sul de Mato Grosso. 